\title{
Cross-Cultural Research Relevance in Public Relations: An Analytical Appraisal
}

\author{
${ }^{1}$ Chinenye Nwabueze, Ph.D,${ }^{2}$ Nnamdi Nweke, ${ }^{3}$ Luke Ejezie \\ ${ }^{1}$ Department of Mass Communication Anambra State University Igbariam Campus \\ ${ }^{2,3}$ (Research Fellow) Department of Mass Communication Anambra State University Igbariam Campus
}

\begin{abstract}
This work is an examination of cross-cultural or intercultural research relevance in public relations. It adopts the analytical approach in exploring the fusion between fact-finding on the cultural environments of the publics of an organization and achievement of mutually beneficial relationship that organization and its publics. Therefore to learn more about public relations practice, it is important to explore the assumptions underlying the issue of cross-cultural research. It was recommended among others, that since public relations agencies, in most cases operate or engage clients who transcend various cultures, it becomes imperative that cross-cultural research would be, particularly, indispensable in achievement of public relations objectives.
\end{abstract}

\section{Introduction}

Professions, people, institutions and organizations do not exist in a vacuum. They exist in a specific culture or socio-cultural environment. Public relations is a profession that basically deals with the maintenance of a good relationship between an organization and its publics. Public relations agencies operate within specific cultural settings. Be it an international or local agency, its operations factor in the cultural settings of the host community of the agency or that of the target audience. Culture is all-encompassing sphere which permeates every facet of life. Public relations is a profession that deals with various publics often sometimes existing in diverse cultures. For any business activity to survive it must thread cautiously in the cultural terrain in order not to hurt the sensibilities and value convictions of business owners, host community members, and target audience. If culture refers to patterns of behaviours and thinking that people living in a social group learn, create and share (Encata Encyclopedia, 2006), then it is a thread that lines the society and its various components, including the professions, disciplines, one of which is public relations.

Ever since Ivy Lee handed out the first fact sheet about public relations to journalists in 1906, public relations has been described as a mediated communication activity used to reach out multiple publics. Prevailing opinion has been that public relations practitioners are in an ideal position to bridge the gap between the media and general public. While it is true that public relations practitioners often perform this boundary-spanning function, the media and the general public are not always the target of public relations activities and communication. In specific terms, the publics of any public relations activity vary according to the organization's mission/vision. It is, perhaps, for this reason that Taylor and Kent (2009:131) state that the practice of public relations focuses on a variety of key publics - shareholders, employees, suppliers, activists, the media and the consumers. However, it may be added that these publics are not stereotyped. They may vary in their intellectual capabilities, educational background, environmental settings, religious inclinations, political ideologies, etc. For this reason, therefore, public relations scholars have examined the roles, functions and assumptions about public relations practices and have found out that the conception and the execution of public relations campaigns/programmes are affected by the cultural nuances upon which the organization publics operate.

Corroborating the above statement, Mclaren, (2003:112) explains thus:

...while the principles of public relations remain the same, it has became apparent that public relations practitioners are aware of how best to carry this out when dealing with their own nations and cultures. However, it has become crucial to recognize that when dealing with a foreign audience it is critical that cross-cultural differences are recognized ... The bottom line is that cross-cultural differences can make or break a public relations campaign. It is, therefore, critical that public relations practitioners, dealing with public relations campaigns that incorporate a cross-cultural element, analyze likely cross-cultural differences.

It is against this background that this paper examines the critical role of cross-cultural research in public relations with a view to ascertaining what public relations agencies ought to do to factor this in, while striving to achieving public relations campaign objectives. 


\section{Culture and Public Relations: The Fusion}

Culture and public relations cannot be separated completely. A thin line divides them because public relations experts need to understand the cultural background of target publics in planning and executing campaign programmes. There is need to take a brief conceptual look at these two key concepts.

There are as many definitions of public relations as there are practitioners - each defining public relations to suit his/her purpose and intentions. Moss in Ajala (2006) defines public relations as a part of every manager's portfolio of responsibilities; a means of understanding and influencing the perceptions held of an organization; a strategic counseling function; a perpetually valuable and cost effective marketing support function; a means of monitoring and managing internal communications; an issue management function; an effective crisis management function; ... reputation management.

For Grunig and Hunt (1984), Public Relations is the management of communications between an organization and its publics. The working definition of public relations in this work is that of the Institute of Public Relations (IPR), United Kingdom which describes Public Relations as the deliberate and sustained efforts to establish and maintain goodwill and mutual understanding between an organization and its publics (cited in Ajala 2006). The word, 'Culture' is laden with several meanings. Ember and Ember (2008) explain that the semantic field for expressing the meaning of culture includes, but not limited to language (the oldest human institution and the most sophisticated medium of expression); arts and sciences (the most advanced and refined forms of human expression); thought (the ways, in which people perceive, interpret and understand the world around them); spirituality (the value system transmitted through generations for the inner well-being of human beings, expressed through language and actions); social activities (the shared pursuits within a cultural community, demonstrated in a variety of festivities and life celebrating events); interaction (the social aspect of human contact, including the give-and-take of socialization, negotiation, protocol and convention). Culture has also been defined as "manifestations of human intellectual achievement regarded collectively, the customs, civilization and achievements of a particular time or people" (Sinclair, in Onyeisi 2007, p.48); "learned socially acquired traditions and lifestyles of the members of a society, including their patterned, repetitive ways of thinking, feeling and acting" (Baran 2004, p.9).Culture describes the many ways in which human beings express themselves for the purposes of uniting with others, forming a group, defining an identity and even for distinguishing themselves as unique.

From the definitions of Public relations and culture offered above, it can be easily seen that both concepts have relationships. The ultimate aim of any public relations activities/programmes is for mutual understanding of the organizations policies, programmes and activities. And this cannot be done in isolation.

The Publics, upon whom the target of all public relations activities are directed, live in a social environment, with defined ways of life. To be able to create, maintain and sustain a favourable relationship with these publics, your programmes must be anchored on the beliefs, attitudes, values, norms, thoughts, arts and languages of that particular society. The crux of the matter is that for a public relations firm and/or consultant to play on these indices of culture, research is imperative. And there lies the relevance of cross-cultural research in operations of Public Relations Agency.

In order for a PR campaign to be successful abroad, an appreciation of the target language and its cultural nuances is vitally necessary. The PR and advertising industries are littered with examples of poor translations and a lack of cross-cultural understanding leading to complete PR failure. Companies entering a foreign market must set aside pre-existing ideas and conceptions - that have no cross-cultural undertones.

Public relations practitioners should, therefore, be prepared to go over translations of documents slogans and literature that must be checked and double-checked for meanings and cross-cultural nuances. It is, also important to keep in mind that this should not only take place between languages and countries but also within languages, in a country/city.

\section{The Concept of Cross-Cultural Research}

In order to do a thorough appraisal of cross-cultural research, especially with regard to the operations of public relations agency, it is important to look, critically, at two concepts - culture and research. It is believed that the dissection of the concepts would provide a concrete foundation for an analytical appraisal of crosscultural research.

Culture, by and large, is a pattern of responses discovered, developed or invented during the group's history of handling problems, which arise from interactions among its members, and between them and their environment. Culture determines what is acceptable or unacceptable, important or unimportant, right or wrong, workable or unworkable. It encompasses all learned and shared, explicit or tacit, assumptions, beliefs, knowledge, norms, and values, as well as attitudes, behavior, dress, and language.

Osuala (2010:1) defines research, as the process of arriving at dependable solutions to problems through the planned and systematic collection analysis and interpretation of oath: Research is a most important tool for advancing knowledge, for promoting progress, and for enabling man to relate more effectively to his environment, to accomplish his purpose and to resolve his conflicts. Wimmer and Dominick (2011:2) define 
research as "an attempt to discover something." However, Nwodu (2006:2) cite Kerlinger (1979). As defining research as a systematic, controlled, empirical and critical investigation of hypothetical pro-position about the presumed relations among natural phenomenon."

The import of the above definitions is that research is all about probing and discovering, through a systematic method, the relationship existing between variables. Meanwhile, such a relationship between variables, which necessitates a problem, must be problematic. In order words, there must be a perceived problem which research efforts strive to provide solution to. There are classes of research, which may range from pure to applied research or historical, scientific, public opinion, legal research etc. However, this paper is concerned with cross cultural research.

\section{Public Relations Research: A cursory look}

Nwabueze,(2006:233) states that through PR research, organizations understand public relations problems, publics, situation, options and come up with the best strategies for ensuring harmony, goodwill, positive perception and mutual favourable relationship with their publics. Through research, an organization scans its environment, detects possible trouble spots and nips emerging crisis in the bud. The essence of PR Motivation Research is to motivate the publics (internal and external) to take certain actions, act in specific ways, or respond to certain issues in peculiar ways. Motivation Research could be carried out on employees, community members, people's culture or any section of the publics depending on organizations intentions or the research objective.

Bahl (1994:160-161) explains that as far as Public Relations is concerned, basic research is of the type conducted by sociologists, Psychologists and other social scientists who try to discover how human beings communicate and interact. The above explanation is apt considering that Public Relations Management activities centre on human interactions. Research is important before executing any Public Relations programme. This explains why Black (1989:122-123) states as follows:

Public Relations is essentially an art of persuasion, and in order to influence people, it is obviously helpful to know as much as possible about the way in which people think and the manner in which they react to particular circumstances. Experience and intuition will provide an answer, but where it is desirable to obtain more factual or statistical data, it is necessary to employ the techniques of motivational research, opinion research ..... Which have been evolved to provide answers to problems.

Public Relations research therefore is the process of fact finding, which explores some techniques of scientific methods, to generate relevant data for solving Public relations problems and/or issues.

\section{Cross-Cultural Research - An Appraisal}

Publi relations is largely communication-based. In dealing with the publics, organizations, individuals, and various public relations clients find that they are faced with audience of diverse cultures. This calls for cross-cultural communication, which according to East-West Business Strategies (2012) is a phrase that describes the ability to successfully form, foster, and improve relationships with members of a culture different from one's own. A basic way of ensuring this is through cross cultural research.

Ember and Melvin (2001) explain that cross-cultural studies, sometimes called Holocultural studies', constitute a specialization in an anthropology and sister sciences (sociology, psychology, economics, political science) that uses field data from many societies to examine the scope of human behavior and test hypotheses about human behavior and culture. Ember and Melvin (2007) add that cross-cultural studies constitute the third form of cross-cultural comparison. The first is comparison of case studies, the second is controlled comparison among variants of common derivations and the third is comparison within a sample of cases.

Tylor and Morgan (2002) argue that unlike comparative studies - which examine similar characteristics of a few societies - cross cultural studies use a sufficiently large sample so that statistical analysis can be made to show relationship or lack of relationships between the traits in question.

Ember and Melvin (2001) inform that the first cross-cultural research was carried out by Abu Rayhan Biruni - who wrote detailed comparative studies on the anthropology of religions, people and cultures in the Middle East, Mediterranean and especially the Indian subcontinent. Ember and Melvin (2001) add that extensive cross-cultural researches were later carried out by $19^{\text {th }}$ century Anthropologists such as Tylor and Morgan, George Murdock, Douglas R White etc.

From the above expositions, therefore, cross cultural research or study is a research that is borderless. Sireci and Berberoghi (2000) explain that the adoption of numerous tests and questionnaires developed for the population of the United States by many researchers in some non-English countries is a classical example of a cross-cultural research. They explain further that if research instruments translated from English become popular in Academics in Taiwan - with satisfactory validity and reliability as the original ones - such is a crosscultural research. Cross-Cultural research is however, not committed to the above examples. For example, Scheuch (1965) argues that cross-cultural research, in the more ambitious meaning of the term, is not necessarily the same as research conducted in more than one country, culture or society. Scheuch (1965) adds 
that a survey of cross-cultural research shows that researchers tend implicitly to treat their own culture as the norm and all others as variations thereof.

Against the background of the above critique, Matsumoto and Juang (2008) avers that cross cultural research goes beyond typical psychological research in that it compares the variables across more than one culture. They observe that most psychological research done in the United States, by its nature is culture specific in that the participants tend to be American. They write that a psychologist in the United State conducting a research study will consider it a job well-done if the sample is ethnically and racially diverse or approximates the population distribution.

\section{Public Relations and Cross-Cultural Research: The Fusion}

Looking at the concepts surrounding the topic of this paper, we can easily and quickly find a synergy among them. Public relations, Culture and Cross-Cultural research are three different concepts which operationally work in tandem to achieve the goals of mutual understanding.

Looking at the definitions of Public relations from the perspectives of the Institute of Public Relations (IPR), UK, and the Mexican Statement (cited in Nweke, 2012), public relations as a management function that evaluates public attitude, identifies the policies and procedures of an organization with the public interest, and executes a programme of action and communication to earn public understanding and acceptance, a concrete synergy among the three concepts would be reached. This is largely a communication-based activity and where the targets of a communication activity exist in diverse cultures, cross-cultural communication which promotes cultural interactivity and understanding is essential. This is largely facilitated through cross-cultural or intercultural research.

Public relations basically entails working with organization's publics (internal and external) who exist under certain cultural menaces and in order to evaluate the attitudes (cultural menaces) of the publics, a research (fact finding) is imperative. Furthermore, owing to the fact that the publics are diverse, cross-cultural fact finding becomes a sine qua none for the operation of public relation activities/programmes. That is where the synergy lies.

Public Relations Agency is a firm that undertakes the job of public relations programmes and activities for an organization. In other words, public relations agency is a consultant that is called in from outside employing organization, to engage or execute public relations programme and activities.

The functions, the roles or the services which a public relations agencies provide to clients include (but not committed to): media relations, employee relations, industrial relations, marketing support, community relations, government relations, crisis management, political campaign management, financial public relations etc.

In all these specialized functions of public relations agencies, cross-cultural research is imperative. First, cross-cultural research could be used to reveal the differences in the diverse culture backgrounds of the target publics of a firm, individual, political party, government, or whoever the client is. Secondly, cross-cultural research could be used to check the extent to which the public relations strategies and programmes are succeeding in the different cultural environments. Bahl (1994:160) explains that the simple logic in looking at the need for cross-cultural research in the operations of Public Relations agencies is obviously from the following points: appreciation of the situation, definition of objectives, choice of media and techniques, budget and assessment of results.

In execution and/or managing a political campaign, for example, a public relations agency, through cross-cultural research has to advice his client (political contestant) on the mode of dressing (to appeal to specific audience), choice of language, etc. For instance, a presidential candidate of Igbo extraction may be advised to learn a bit of Hausa and/or Yoruba greetings and to put on Hausa or Yoruba attires while addressing them in a political rally. In any campaign rally, if the person speaks a people's local language, this could capture the support of the audience.

Furthermore, cross cultural research could play vital roles in political marketing, which is an extension of public relations. For instance, President Goodluck Ebele Azikiwe Jonathan, his Igbo names helped to market him a lot among the Igbos. Also his visit to Anambra State during his campaign and project inspection where he dressed in Igbo native attire (Isiagu with Aka regalia, Chieftaincy walking stick and red cap) was an attempt to create positive or mutual relationship and acceptance with Igbo people. This is an adoption of dressing or dress code as a cultural factor in political marketing. Cross-cultural research elicits information about the culture of target publics which is different from that of the public relations practitioner's client.

Imo State Governor Chief Rochas Okorocha during the 2007 Presidential campaign, always dressed in attires of various tribes, (Hausa, Igbo, Yoruba etc.) and spoke the local language of some of these ethnic groups as a way of endearing the electorate to himself and his party. This helped him to be known politically all over Nigeria. It further buttresses the place of language as a factor in breaking cultural barriers. During the 1999 Presidential Primary Election campaigns, Chief Jim Nwobodo used his knowledge of Hausa language to woo 
Hausa supporters to Chief Olusegun Obasanjo during a campaign in Jos, that was when the two political gladiators were together in Peoples Democratic Party (PDP).

Again, a public relations consultant who is engaged to manage a community relationship and/or environmental public relations management, would have to advise his client (oil firm, for example) to lie down if he pays a courtesy call on the Oba of Benin (for example) or to genuflect if he is greeting elderly community leaders etc. This is part of the essence of cross-cultural research of public relation practice. It ensures effective cross-cultural communication which is essential to achievement of public relations goals.

\section{Conclusion}

This paper is about the relevance of cross-cultural research in the operations of public relations agency. In appraising this topic, three concepts which have direct bearing to the topic - were x-rayed. The concepts include: Public relations, Culture, and Cross-cultural research. An overview of these concepts was done with a view to providing a construct/foundation for the study as well as drawing a synergy on the topics.

The expositions made in the overviews point out to the fact that the operations of public relations agency cannot be done without a sound cross-cultural research - which is carried out to ascertain the attitudes of the publics concerned, or to ascertain why and how a certain opinion is held of an organization as well as the effects (negatives or positives) such held opinions on the survival of the organization. It was observed that the research is Sine-qua-none to the operatives of PR Agency.

Since public relations agencies, in most cases operate with or engage clients whose target publics are diverse, it becomes imperative that cross-cultural research would be, particularly, indispensable in achievement of public relations objectives. This is why it is also recommended that mandatory relevant degree and/or professional certificate education should be a condition for Public Relations practitioners. Public relations executives of various organizations and agencies should embark on regular training on the basics of crosscultural research with a view to understanding the cultural environment of various publics which they (PR executives and professionals) deal with in order not to offend their sensibilities. This is because public relations is communication driven, and cross-cultural research will improve cross-cultural communication which describes the ability to successfully form, foster, and improve relationships with members of a culture different from one's own. There is need for a regular cross-cultural training programme for public relations practitioners because this would provide them with the knowledge, understanding, and skills they need to communicate and cooperate effectively across cultural barriers. Research of any type is crucial to the achievement of public relations objectives.

\section{References}

[1] Ajala,V. (2006). Public Relations: In search of Professional Excellence( $2^{\text {nd }}$ Ed), Ibadan: University Press.

[2] Bahl, S. (1994). Making Public Relations work. India: A.H. Wheeler and Co. Ltd.

[3] Baran,S.J. (2004). Introduction to Mass Communication: Media Literary and Culture, $3^{\text {rd }}$ edition. Boston: McGraw Hill.

[4] Black, S. (1999). Introduction to Public Relations, London: Modino Press Ltd.

[5] East-Western Business Strategies (2012). What is cross-cultural communication? www.ewbs.com/descr.html. Retrieved 6-05$\underline{2012 .}$

[6] Ember,C.K. and Melvin, E. (2008). Cross-Cultural Research-Handbook of Methods in Cultural Anthropology http://en. Wikipedia.org/wiki/culture/2008/3.

[7] Ember,C.K. and Melvin, E. (2001). Cross-Cultural Research Methods sagebook: http://www.sagepublications.com.

[8] Grunig, J. and Hint, J. (1984).Managing Public Relations: New York: Holt, Rinehart and Winston Inc.Hollonda, T. (2008)."Issues of Cross-Cultural Research."http://www.roshan-institute.org/474532/2008.

[9] Aluko, M. A. (2003). Impact of Culture on Organisational Performance in Selected Textile Firms in Nigeria. Nordic journal of African studies, 12(2):164-179.

[10] Matsumoto, K. and Juang, U. (2008). "Cross-Cultural Research-Mixed methods in international collaborative Research,"http://ssi.sagepub.com/conttent/6/5/7--extract.

[11] Mclaren, P. (2003). Life in School: An Introduction to Critical Pedagogy in the Foundations of Education, (4 ${ }^{\text {th }}$ Ed). Boston: Allyn and Bacon.

[12] Nwabueze, C. (2006). Marketing Communications Principles and Practice, Enugu: Daisy Press Publishers.

[13] Nwodu, L.C. (2006). Research in Communication and other Behavioural Sciences -Principles, methods and issues, Enugu: RhyceKerex Publishers.

[14] Onyeisi, E. N (2007). Cultural Mobilization through Drama. Journal of Nigerian Languages and culture, 9(1):48-50.

[15] Osuala, E.C. (2010). Introduction to Research Methodology ( $2^{\text {nd }}$ Ed) Onitsha: African fep Publishers Ltd.

[16] Seheuch, E.K. (1965). "Society as context in Cross-Cultural comparison" http://www.the sportjounal.org./Retrieved 2009/001.

[17] Simmel,G.(2004). “DefiningCulture-TheMulti-PerspectiveApproach"http://www. Businessdictionary.com/definition/culture//html.

[18] Taylor, M. and Kent, M.L. (2009). “Challenging Assumptions of International Public Relations” Public Relations Review, 25 (2)

[19] Velkley, R. (2011). "Culture - Definitions and Meanings” http://enWikipedia.org/wiki/culture/2012/13.

[20] Wimmer, D. R. and Dominick, J.R. (2011). Mass Media Research - An Introduction ( $9^{\text {th }}$ Ed.). Canada: Wadsworth. 